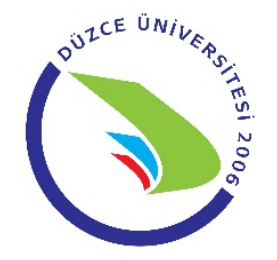

\title{
Tip 1 Diyabetli Adolesanlarda Web Tabanlı Egzersiz Eğitiminin Etkinliği
}

\author{
Seltap GÜLCÜ 國, Sevda ARSLAN 國 ${ }^{1}$, İlknur ARSLANOĞLU [ $^{3}$
}

\section{ÖZ}

Amaç: Bu çalışma web tabanlı hazırlanmış diyabetli adölesanlarda egzersiz eğitim modülünün bireylerin mevcut alt yapısına göre uygulanabilirliği ile bilgi düzeyi, adölesanların diyabet yönetimi ve egzersize bakışı üzerine etkilerini belirlemek amacıyla yarı deneysel, prospektif bir çalışma olarak yapıldı.

Gereç ve Yöntemler: Çalışma bir üniversite hastanesinde Kasım 2018- Aralık 2018 tarihleri arasında gerçekleştirildi. Çalışma protokolüne uygun 10-18 yaş aralığındaki hasta popülasyonundan çalışmayı kabul eden 65 adölesan çalışmaya alındı. Çalışma grubuna her hafta bir eğitim olmak üzere beş hafta süren web tabanlı egzersiz eğitimi verildi. Veri toplamada diyabetli adölesanları tanılamak, web sitesinin etkinliğini, eğitim öncesi ve sonrası bilgi düzeylerini ve egzersiz yapmak ile ilgili kararlarını belirlemek amacı ile test ve formlar kullanıldı.

Bulgular: Yapılan çalışma sonucunda eğitim sonrası diyabetli adölesanların egzersiz yapma kararı sorgulandığında 49 kişiden sadece \%2'sinin $(n=1)$ egzersiz yapmayacağım şeklinde karar aldığı diğerlerinin ise olumlu dönüşümler yaptığı ve \%57,1'inin ise (n=28) kararlı bir şekilde egzersiz yapmak istediği saptandı. Bilgi test sonuçları değerlendirildiğinde ise eğitim öncesi yanlış sayısında eğitim sonrası anlamlı bir azalma meydana geldiği $(\mathrm{p}=0,038)$ belirlendi. Çalışmaya katılan diyabetli adölesanlar düzensiz de olsa $\% 94,8$ 'nin bedensel harekette bulunduğu ve $\% 53,4$ 'nün de düzenli spor yaptığı belirlendi.

Sonuç: Çalışmadan elde edilen sonuçlara göre tip 1 diyabetli adölesanların eğitim ve izleminde, web tabanlı eğitim siteleri tamamlayıcı bir araç olarak kullanılabilir.

Anahtar Kelimeler: Diyabet; internet tabanlı eğitim; adölesan.

\section{The Efficiency of Web Based Exercise Training in Adolescents with Type 1 Diabetes}

\begin{abstract}
Aim: This study was conducted as a quasi-experimental, prospective study in order to determine the applicability of exercise training module according to the existing infrastructure and knowledge level, diabetes management and view of exercise in web-based diabetes.

Material and Methods: The study was conducted in a university hospital between November 2018 and December 2018. Sixty-five adolescents who accepted the study from the 10-18 age group in accordance with the study protocol were included in the study. Web based exercise training lasted 5 weeks. Test and forms were used to collect data to identify adolescents with diabetes, to determine the effectiveness of the website, their level of knowledge before and after education, and to decide on exercise.

Results: As a result of the study, when the decision to exercise after training was questioned, only $2 \%$ of 49 people $(n=1)$ decided that they would not exercise and the others made positive transformations and $57.1 \%(n=28)$ wanted to exercise determinedly. When the knowledge test results were evaluated, it was determined that there was a significant decrease in the number of misconceptions before training $(p=0.038)$. It was determined that $94.8 \%$ of the diabetic individuals participating in the study were in physical movement and $53.4 \%$ of them were doing regular sports.
\end{abstract}

1 Düzce Üniversitesi Tıp Fakültesi, Sağlık Uygulama Araştırma Merkezi, Düzce, Türkiye

2 Düzce Üniversitesi Sağlık Bilimleri Fakültesi, Hemşirelik Bölümü, Düzce, Türkiye

3 Düzce Üniversitesi Tıp Fakültesi, Dahili Tıp Bilimleri Bölümü, Düzce, Türkiye

Sorumlu Yazar / Corresponding Author: Seltap GÜLCÜ, e-mail: glcsltp@gmail.com

Geliş Tarihi / Received: 09.07.2019 Kabul Tarihi / Accepted: 23.06.2020 
Conclusions: According to the results of the study, webbased educational sites can be used as a complementary tool in the education and follow-up of adolescents with type 1 diabetes.

Keywords: Diabetes; web based education; adolescent.

\section{GíRiş}

Diyabet, insülin etkisindeki defektler ya da insülin eksikliği nedeniyle organizmanın karbonhidrat, yağ ve proteinlerden yeterince yararlanamadığı, sürekli tıbbi bakım gerektiren, kronik bir metabolizma hastalığıdır (1). Çocukluk yaşı grubunda sık görülen Tip 1 diyabet ise insülin üretiminde görevli pankreasın beta hücrelerinin otoimmün veya dış nedenlerle tahrip olması sonucu gelişen insülopeni ve hiperglisemi ile karakterize edilen kronik metabolik bir hastalıktır (2).

Uluslararası Diyabet Federasyonu (International Diabetes Federation ( IDF) ) 2017 verilerine göre dünyada 425 milyon diyabetli hasta (11 yetişkinden 1'i) ve 2045 yılında 629 milyon diyabet birey olacağ 1 tahmin edilmektedir. Dünyada tip 1 diyabete sahip 1 milyondan fazla çocuk ve adölesan bulunmaktadır. Ülkemizde ise 25,669 tip 1 diyabetli hasta bulunmaktadır. 2017 yılında diyabet tedavisi için 727 milyar ABD doları harcandığ 2045 'te ise 776 milyar ABD doları harcanacağ edilmektedir. $\mathrm{Bu}$ durum diyabet olan kişilerin diyabeti olmayanlara göre iki kat fazla sağlık maliyetinin olduğu anlamına gelmektedir (3).

Çocuklar büyüdükçe ve geliştikçe daha fazla bağımsız olmak istemekte ve bununla birlikte davranış değişiklikleri ve uyum güçlükleri görülebilmektedir. Adölesan dönemde diyabet hastası olanlar da akranlarına benzer davranış değişiklikleri yaşamaktadır. Adölesanda diyabete yönelik tepkiler, adölesanın kendisine ne olduğunu algılama kapasitesine göre değişiklik göstermektedir. Şok ve inkârdan diyabet tanısını kabullenmeye kadar geçen sürede yaşanan uyumsuzluklar doğal karşılanmalıdır (4). Ayrıca tip 1 diyabet tedavisinin karmaşık ve çok boyutlu olması nedeni ile çocuk ve adölesanlar bazen diyabet yönetiminde zorluk yaşamaktadır. Diyabet hastası olan adölesanların içinde bulundukları bu süreçte başarılı diyabet yönetimi, aile işbirliğine dayalı düzenli diyabet eğitiminin verilmesi ve problem çözme becerilerinin kazandırılması ile sağlanacaktır $(5,6)$.

Yapılan çalışmalar göstermiştir ki diyabet eğitimi bakım sonuçlarını iyileştirmiş, komplikasyonları ve hastanede yatışları azaltmış ve bakım maliyetlerini düşürmüştür $(8,9)$. Ayrıca diyabet eğitimi glisemik kontrolün sağlanmasını, bilgi düzeyinin artmasını, özyönetim davranışı ve hastalığa uyumu olumlu olarak etkilemektedir $(10,11)$. Özellikle tip 1 diyabette eğitim hasta merkezli, yaşa, gelişim özelliklerine, alg1 durumuna, öğrenme koşullarına, ihtiyaca yönelik ve eğitimlere aktif katılım ile sağlanmalıdır (12). Bu nedenle adölesanların periyodik olarak eğitim ve psikososyal yönden desteğe ihtiyacı vardır.

Diyabetli hastalar için düzenli egzersiz tıbbi tedavinin ve beslenme programının önemli bir basamağıdır. Tip 1 diyabette egzersiz; insülin gereksinimini azaltma ve etkisini arttırma, kan glikoz kontrolünü sağlama, kasların gücünü arttırma, tartı kontrolünü sağlama, kemiklerin gelişimini ve güçlenmesini sağlama, kardiyovasküler sistemi olumlu yönde etkileme, kan yağlarını azaltma, kondüsyonu arttırma, yaşam kalitesini yükseltme, kendine güveni arttırma, stresi azaltma gibi çok sayıda yarar sağlamaktadır (13). Tip 1 diyabetli hastalarda egzersizin süresi, şiddeti, tipi ve bireyin metabolik yanıta duyarlılığı oldukça önem arz etmektedir. Ayrıca egzersiz yapılırken risklerin (hiperglisemi, hipoglisemi) nasıl yönetileceği (beslenme ve insülin doz ayarlaması) mutlaka bilinmelidir (14). Diyabetli hastalarda egzersiz eğitimleri ile egzersizde glisemik yanıtın düzenlenmesi sağlanabilir. Yapılan çalışmalarda tip 1 diyabetli adölesanların akranlarına göre fiziksel aktivite kapasitelerinin daha düşük olduğu belirtilmektedir $(13,15)$. Bunun nedeni olarak ise egzersize bağl hipoglisemi yaşama korkusu olduğu bildirilmektedir $(15,16)$. Diyabet otoritelerinin de belirttiği üzere gerekli önlemler alındıktan sonra diyabetli çocuklar ve adölesanlar her türlü egzersizi yapabilirler (14).

Günümüzde özellikle internet kullanımının artması ile eğitim amacıyla internet yoğun kullanılmaya başlanmıştır. İnternet kullanımı dünyada \%53 iken ülkemizde \%67'dir (18). Türkiye İstatistik Kurumu (TÜİK) Türkiye İstatistik Kurumu 2019 hane halk1 bilişim teknolojisi kullanım araştırması verilerine göre 16-74 yaş aralığındaki bireylerin masaüstü bilgisayar kullanımı \%10, cep telefonu kullanım \%57,3'tür. TÜİK 2013 internet kullanımına yönelik verilerine göre 06-15 yaş aralığındaki bireylerin internet kullanımı \%50,8'dir (19). $\mathrm{Bu}$ oran günümüz şartlarında daha fazla olduğu görülmektedir. Kullanım nedenlerine bakıldığında ise gereksinim duyulan bilgiyi seçme ve istediği zamanda ulaşabilme, maliyet azlığı, sinırlılıklar nedeniyle işyerinden, okuldan ya da evden ayrılmak zorunda kalmalarıdır (7). Avrupa da ve ülkemizde diyabet eğitim hemşiresinin rolünün kabullenmesine rağmen hem diyabet hemşiresi sayısının azlığı hem de poliklinik ortamlarının kalabalıklığı, diyabet hastalarının düzenli eğitimlerini ve izlemlerini kısıtlamaktadır (20). Farklı yaklaşımlar ve eğitim modelleri kullanılarak diyabette süreklilik gerektiren eğitim dinamik hale getirilebilir. Bu nedenle internet ortamında diyabet eğitimi sağlayacak bir site oluşturulması ile farklı mesafede yaşayan ve çeşitli nedenlerle poliklinik hizmeti alamayan diyabetli adölesanların gereksinim duyduğu bilgiye kolayca ulaşması, sağlık sisteminden daha fazla yararlanmasını sağlayarak diyabet bakımını geliştireceği düşünülmektedir.

Literatür incelendiğinde çalışmalar sınırlı olmakla birlikte düzenlenen web sitesi aracılığı ile tip 1 diyabetlilere diyabet eğitimi verilmiş, uzmanlara ulaşım ve akran etkileşimi sağlanmıştır. Web sitelerin etkinlikleri ise farklı yöntemlerle değerlendirilmiştir. Genellikle altı ay ile iki yıl arasında yapılan çalışmalarda web tabanlı diyabet eğitiminin $\mathrm{HbAlc}$ ve metabolik kontrol üzerine olumlu etkisi olduğu saptanmıştır (21-23). Ayrıca tip 1 diyabetli adölesanlara chat odaları ve bloglar yoluyla uzmanlara ulaşımın sağlanmasında, akran desteğinin oluşturulmasında ve başarılı diyabet yönetiminin sağlanmasında (24) önemli olduğu bildirilmektedir $(21,23,25)$. Yapılan çalışmalarda diyabetlilerin web sitesi uygulamasından memnun kaldığı (26) ve web sitesinin 
klinik kaynaklara ekonomik yük getirmediği konusunda olumlu olduğu bulunmuştur.

Gelișen teknoji ile birlikte ülkemizde tip 1 diyabetli adölesanlara yönelik web tabanlı eğitimlerin oluşturulmasını ve uygulanmasını konu alan çalışmaların yeterli olmaması bu alanda eksiklik oluşturmaktadır. Bu çalışmada tip 1 diyabetli adölesanlarda internet ortamında verilen diyabette egzersiz eğitiminin etkinliğini değerlendirmek ve eğitim sonunda egzersiz yapmaya karar verme durumları üzerine etkisini incelemek amaçlanmıştır.

\section{GEREÇ VE YÖNTEMLER Araştırma Türü}

Yarı deneysel, prospektif, klinik tipteki bu çalışma, Düzce Üniversitesi Araştırma ve Uygulama Hastanesi Çocuk Endokrinoloji ve Metabolizma Hastalıkları polikliniğinde Kasım 2018-Aralık 2018 tarihleri arasında yürütülmüştür.

\section{Araştırma Evreni ve Örneklemi}

Çalışma grubu Düzce Üniversitesi Araştırma ve Uygulama Hastanesinde Çocuk Endokrinoloji ve Metabolizma Hastalıkları polikliniğinde Tip 1 diyabet tanısı ile takip edilen 10 ile 18 yaş arasındaki bireylerden oluşturuldu. Çocuk Endokrinoloji ve Metabolizma Hastalıkları polikliniğinde kayıtlı olup kontrollerine devam eden, dahil etme ve hariç tutma kriterlerine uygun olduğu değerlendirilen, hasta sayısının 150 olduğu tespit edilmiştir. Bu hastalardan örneklem özelliklerine uygun olup araştırma hakkında bilgi verilen diyabetli adölesanların 65'i çalışmaya gönüllü olarak katılmayı kabul etmiştir. Beş haftalık çalışma süresince dört kişi okul sinavları, yoğunluk, internet problemi gibi nedenlerle çalışma 61 tip 1 diyabetli adölesan ile tamamlanmıştır.

\section{Veri Toplama Araçları}

Verilerin toplanmasında; araştırmacılar tarafindan oluşturulan Tip 1 Diyabetli Adölesan Kişisel Bilgi Formu, Tip 1 diyabetli adölesanların egzersiz yapmakta engel olarak değerlendirdiği durumlarının belirlenmesi için Egzersiz ve Diyabet Hakkında Düşünceler Formu, web sitesinin değerlendirilebilmesi için Web Sitesi (Materyali) Değerlendirme Formu (Öğrenci), eğitim öncesi ve sonrası bilgi düzeyinin belirlenmesi amacı ile Eğitim Öncesi ve Sonrası Bilgi Testi kullanılmıştır. Web tabanlı egzersiz eğitiminin verilmesi için ise $\mathrm{Web}$ tabanlı Tip 1 diyabet egzersiz eğitim sitesi kurulmuştur.

Tip 1 Diyabet Hastası Olan Adölesan Kişisel Bilgi Formu: Form, araştırma kapsamına alınan diyabetli adölesanların sosyo demografik bilgilerinin elde edilmesi amaciyla konuyla ilgili literatürden yararlanılarak hazırlandı. Bu form diyabet merkezine uzaklık, kan şeker ölçüm sıklığg1, hipoglisemi ve hiperglisemi yaşama sıklığg, glukagon kullanımı, ketoasidoz yaşama durumu, kalp hastalığı, karbonhidrat sayımı ve beslenme, düzenlidüzensiz ve lisanslı spor yapma durumu, beden eğitim derslerine katılma durumlarını sorgulayan 36 sorudan oluşturuldu $(1,6,11,13)$.

Egzersiz ve Diyabet Hakkında Düşünceler: Kapalı uçlu sekiz sorudan oluşturuldu. Eğitim öncesi ve sonrası uygulandı. Eğitim sonrasında bireylerin egzersiz yapma niyetlerini değerlendirmek için forma ilave bir soru (Bu eğitimler sonunda egzersiz yapmak ile ilgili kararınız aşağıdaki seçeneklerden hangisidir?) daha eklenerek dokuz soruya tamamland.

Web Sitesi (Materyali) Değerlendirme Formu (Öğrenci): Form, katılımcıların eğitim materyali olarak kullanılan Web sayfasını çeşitli yönlerden değerlendirmesini sağlayan toplam 45 sorudan oluşmaktadır. Değerlendirme forumunda bulunan sorular Oğuz Çetin tarafindan doktora tezi için Millî Eğitim Bakanlığı'nın “Web Sitesi Hazırlama Kuralları'ndan ve "Eğitim Yazılımları Değerlendirme Formu'ndan (MEB) yararlanarak hazırlanmış olup Oğuz Çetin'in doktora tez çalışmasında kullanıldı (27). Bu çalışmada kendisinden izin alınarak sorular üzerinde her hangi bir değişiklik yapılmadan kullanıldı. Formun iç tutarlılık kat sayısı 0,7958 olarak hesaplanmıştır. Söz konusu formda yer alan ilk 12 soru Görsel Yeterliliği, 13-31 nolu sorular Teknik Yeterliliği ve

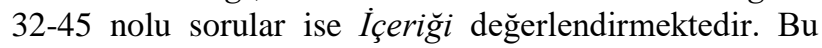
çalışmada sonuçları daha iyi ifade edebilmek için üç alt boyut puan ortalamaları ve ölçeğin genel ortalama puanı elde edildi. Her bir alt boyutta farklı sayıda sorular yer alması nedeniyle ortalama puanlar hesaplandı. Tüm sorular 5, li Likert tipinde olup ortalama puanın maksimum değeri beştir. Alt boyutların kendi içinde ve genel olarak tüm sorular arasındaki iç tutarlılık değerleri incelendiğinde şu sonuçlara ulaşıldı; Görsel yeterlilik alt boyutunda katsayı değeri 0,800, Teknik Yeterlilik alt boyutunda 0,876 ve Içerik alt boyutunda 0,898 bulundu. Ayrıca ölçeğin genel iç tutarlılık katsayısı 0,930 olarak hesaplandı. $\mathrm{Bu}$ sonuçlar iç tutarlılığın hem alt boyutlar düzeyinde hem de ölçeğin genelinde oldukça yüksek olduğunu göstermektedir.

Ĕ̆itim Öncesi ve Sonrası Bilgi Testi; Eğitim öncesi konuya dikkat çekmek ve eğitim sonrası egzersiz ile ilgili bilgi düzeyini ölçmek, ünitedeki hedef davranışlara ulaşılıp ulaşılmadığını belirlemek amaçlı kapalı uçlu çoktan seçmeli 33 sorudan oluşturuldu (1,2,11,13-15,1923).

Web tabanlı Tip 1 diyabet egzersiz eğitim sitesi

-Diyabetli adölesanın kullanıcı ekranı

Deney grubunun eğitimi, yazışmaları, istenilen anketlerin doldurulma durumlarının takibi, diyabetli kullanıcı ekranı üzerinden yürütüldü. Tip 1 diyabetli adölesan kişisel bilgi formu, internet kullanımına ilişkin özellikler, egzersiz ve diyabet hakkında düşünceler, web sitesi (materyali) değerlendirme formu (öğrenci), eğitim öncesi ve sonras1 bilgi testi sisteme yüklendi. Beş haftalık eğitim süresince her hafta bir eğitim sisteme eklendi ve eğitimleri izleme süreleri, bilgi testi ile formların doldurulma durumları sistem üzerinden takip edildi. İzlenmeyen eğitimler ve doldurulmayan formlar için kullanıcılara sistemden mesaj gönderildi. Telefon ile aranarak da hatırlatma yapıldı.

-Diyabetli adölesanın kullanıcı ekranı yapılandırma süreci

Diyabetli adölesanların takibi amacıyla bir web sitesi hazırlandı. Sitenin kullanıcı profili, kullanıcı (diyabetli adölesan) ve yönetici (sağlık profesyoneli) olarak ikiye ayrıldı. Yöneticilerin çalışmadaki sorumluluğu, sitenin teknik yönetimi ve kullanıcılarla iletişim kurması olarak belirlendi.

Yazılımın geliştirilmesinde araç olarak Microsoft Visual Studio.NET 2013, programlama dili olarak Asp.Net MVC ve veri tabanı olarak Microsoft SQL SERVER 2017 kullanıldı, ara yüzde tüm platformlarda uygun 
kullanımı sağlayan responsive tasarım oluşturuldu ve bootstrap yapısı aktif olarak kullanıldı. Site güncel tüm tarayıcılarda ve mobil platformda sorunsuz bir şekilde çalışacak yapıda tasarlandı.

\section{Araştırmanın Etik Boyutu}

Araştırmanın yapılabilmesi için Düzce Üniversitesi Tıp Fakültesi Girişimsel Olmayan Sağlık Araştırmaları Etik Kurulu'ndan 10.07.2017 tarih ve 2017\83 sayılı etik kurul onayı ve Düzce Üniversitesi Araştırma ve Uygulama Hastanesi'nden resmi kurum izni alındı. Feyzioğlu'ndan anket kullanım izni alındı. Araştırma için diyabet hastalarına ve ailelerine çalışmanın amacı ve web sitesi ile ilgili gerekli açıklamalar yapılarak sözlü onamları alındı. Diyabet hastalarına araştırmaya dâhil olma ve istedikleri zaman ayrılma konusunda özgür oldukları, yapılan işlemler için aileye veya bağlı olunan sosyal güvenlik kuruluşuna bir araştırma gideri yüklenmeyeceği, ayrıca bireysel bilgilerin gizli tutulacağı konusunda açıklama yapılarak, "gizlilik ilkesine" uyuldu.

\section{İstatistiksel Analiz}

Elde edilen verilere ait tanımlayıcı değerler, ortalama, standart sapma, sayı ve yüzde frekanslar olarak verildi. Sayısal tipteki verilerin normal dağılıma uyumu Kolmogorov-Smirnov testi ile incelendi. Web tabanl eğitimin ölçek puanları üzerindeki etkisi, eğitim öncesi ve sonrası bilgi puanları ile "Egzersiz ve diyabet hakkında" düşüncelerin değişimi Wilcoxon sign rank test ile incelendi.

\section{BULGULAR}

Çalışmaya katılan toplam 61 kişinin \%52,5’i (32) kız, \%47,5'i (29) erkekti. Katılımcıların yaş ortalamaları 13,12 $\pm 2,29$ (min:10,00-maks:18,00), boy ortalamalar1 154,67 $\pm 13,31 \quad$ (min:126,50-maks:190,50) cm, kilo ortalamalar1 $\quad 51,23 \pm 16,64 \quad$ (min:24,30-maks:104,90), vücut kitle indeksleri ortalamaları 20,91 $\pm 4,43$ (min:13,47-maks:39,48) olduğu belirlendi. Katılımcıların \%42,6’sı (26) Düzce ili diğerleri Düzce dışında yaşayan kişilerden oluşmaktaydı (Tablo 1).

Tablo 1. Tip 1 Diyabetli Adolesanların Tanıtıcı Özellikleri

\begin{tabular}{|l|l|c|c|c|c|}
\hline & n & Ortalama & $\begin{array}{c}\text { Standart } \\
\text { sapma }\end{array}$ & Min. & Maks. \\
\hline Yaş & 58 & 13,12 & 2,29 & 10,00 & 18,00 \\
\hline Boy & 59 & 154,67 & 13,31 & 126,50 & 190,50 \\
\hline Kilo & 59 & 51,23 & 16,64 & 24,30 & 104,90 \\
\hline VKI & 59 & 20,91 & 4,43 & 13,47 & 39,48 \\
\hline
\end{tabular}

VKI:Vücut kitle indeksi, Min: Minimum, Maks: Maksimum

Diyabetli adölesanların \%53,4'ü $(n=31)$ düzenli spor yaptığını, \%46,6'sı (n=27) ise düzenli spor yapmadığını ifade etti. Düzenli spor yapanların \%54,8'ü $(n=17)$ haftada 1-3 gün, \%32,2’sı (n=10) 4-6 gün, \%12,9’u (n=4) 7 gün düzenli spor yaptığı belirlendi. Katılımcıların \%29,3'ü $(n=17)$ lisanslı spor yaptığı, lisanslı spor

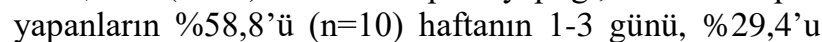
(n=5) 4-6 günü, \%11,7'si (n=2) 7 günü yaptığ 1 belirlendi. Diyabetli adölesanların düzensiz olsa da \%96,5'inin $(n=56)$ oyun veya bedensel harekette bulunduğu, $\% 3,4$ 'sinin $(n=2)$ bulunmadığı belirlendi. Düzensiz olsa da oyun veya bedensel harekette bulunanların \%67,9'u (n=38) haftanın 1-3 günü, \%17,9’u $(n=10)$ 4-6 günü, $\% 14,3$ 'ü $(n=8) 7$ günü düzensizde olsa oyun veya bedensel hareket yaptığı belirlendi. Katılımcıların oyun ve egzersiz sırasında yaşadıkları sorunlar sorgulandığında $\% 48,3$ 'ü $(n=29)$ hipoglisemi yaşadığını, \%5‘i $(n=3)$ hiperglisemi yaşadığını, \%1,7'si $(n=1)$ hem hipoglisemi hem hiperglisemi yaşadığını, \%45,0'i ( $\mathrm{n}=27)$ ise hiçbirini yaşamadığını ifade etti. Diyabetli adölesanların $\% 82,0$ 'sinin $(n=50)$ beden eğitimi öğretmeni diyabetli olduğunu bilirken, \%18'nin $(n=11)$ bilmediği belirlendi. Katılımcıların beden eğitimi derslerine katılım durumları incelendiğinde, $\% 96,7^{\prime} \operatorname{sinin} \quad(n=59)$ beden eğitimi derslerine katılım gösterirken, $\% 3$,3'ünün $(n=2)$ katılım göstermediği belirlendi. Beden eğitimi derslerine katılmayan diyabetli adölesanların neden katılım göstermedikleri sorgulandığında \%33,3'ü $\quad(n=1)$ hipoglisemi yaşamaktan korktuğu için, \%33,3'ü $(n=1)$ ailesinin ve \%33,3'ü $(n=1)$ öğretmenin katılmasını istemediği için beden eğitimi derslerine katılmadığını ifade etti (Tablo 2).

Bilgi testine cevap veren katılımcıların doğru yaptıkları, yanlış yaptıkları ve boş bıraktıkları soru sayılarına ait tanımlayıc1 istatistikler Tablo 3' te verildi. Bilgi testinde yaptığı doğru soru sayısı, yanlış soru sayısı ve boş bıraktığı soru sayısında eğitim sonrası meydana gelen değişim incelendiğinde, hem eğitim öncesi hem de eğitim sonrasi toplam 61 katılımcidan 52' sinin bilgi testine cevap verdiği belirlendi. 52 kişinin test sonuçları değerlendirildiğinde ise eğitim sonrası doğru sayısında anlamlı bir değişim olmadığı, yanlış sayısında eğitim sonrası anlamlı bir azalma meydana geldiği $(p=0,038)$ ve boş soru sayısında ise eğitim sonrası anlamlı artış olduğu gözlendi ( $p=0,040)$ (Tablo 3).

Eğitim sonrası diyabet hastalarının egzersiz ve diyabet hakkındaki düşüncelerinin ne yönde değiştiğini sorgulamak için Tablo 4' te tanımlanan 8 soruya ilaveten "egzersiz yapma kararınız nedir?" sorusu eklenmiștir. Bu soruya egzersiz yapmaya karar verdim diyenler \%57,1 (28), kararsızım diyenler \%16,3 (8), egzersiz yapmayı deneyeceğim cevabını verenler \%24,5 (12) ve egzersiz yapmayacağım diyenler \%2 (1) olarak belirlendi. Bu soruya toplam 49 kişi cevap verdi. Eğitim öncesi çok iyi cevabını veren 11 kişinin eğitim sonrası 1' i kötü, 1' i biraz daha gayret etmem gerek cevabını, 1' i orta, 5' i iyi ve 3' ünün çok iyi cevabını verdiği belirlendi. Sonuçlar değerlendirildiğinde bu soru için eğitim öncesi ve sonrası verilen cevaplarda anlamlı bir değişim olmadığı görüldü $(p=0,060)$. Sonuç olarak eğitim sonrası eğitim sonunda egzersiz yapma kararınız nedir sorusuna cevap veren 49 kişiden sadece 1 kişinin egzersiz yapmayacağım şeklinde karar aldığını diğerlerinin ise olumlu dönüşümler yaptığı ve \%57,1' inin ise $(n=28)$ kararlı bir şekilde egzersiz yapmak istediği belirlendi (Tablo 4).

Araştırmada elde edilen Görsel yeterlilik değerlendirme puan ortalamas1 3,96 $\pm 0,54$ (min:2,67-maks:5,00), Teknik Yeterlilik değerlendirme puan ortalaması $3,85 \pm 0,56$ (min:2,63-maks:5,00), İçerik değerlendirme puan ortalamas1 4,04 $\pm 0,59$ (min:2,46-maks:5,00), Web sitesi değerlendirme Genel ortalama puanı 3,96 $\pm 0,51$ (min:2,96-maks:5,00)' dir (Tablo 5). 
Tablo 2. Tip 1 Diyabetli Kişisel Bilgi Formunda Yeralan Egzersiz Yapma Durumuna İlişkin Sorulara Verilen Cevapların Dağılımı

\begin{tabular}{|c|c|c|c|}
\hline & & $\mathbf{n}$ & $\%$ \\
\hline \multirow{2}{*}{ Düzenli Spor Yapma Durumu } & Evet & 31 & 53,4 \\
\hline & Hayır & 27 & 46,6 \\
\hline \multirow{3}{*}{ Yapılan Düzenli Sporun ( Haftada) Gün Sayısı } & 1-3 gün & 17 & 54,8 \\
\hline & 4-6 gün & 10 & 32,2 \\
\hline & 7 gün & 4 & 12,9 \\
\hline \multirow{2}{*}{ Lisanslı Spor Yapma Durumu } & Evet & 17 & 29,3 \\
\hline & Hayır & 41 & 70,7 \\
\hline \multirow{3}{*}{ Yapılan Lisanslı Spor ( Haftada) Gün Sayısı } & 1-3 gün & 10 & 58,8 \\
\hline & 4-6 gün & 5 & 29,4 \\
\hline & 7 gün & 2 & 11,4 \\
\hline \multirow{2}{*}{$\begin{array}{l}\text { Düzensizde Olsa Oyun } \backslash \text { Bedensel Harekette Bulunma } \\
\text { Durumu }\end{array}$} & Evet & 56 & 96,5 \\
\hline & Hayır & 2 & 3,4 \\
\hline \multirow{3}{*}{$\begin{array}{l}\text { Düzensizde Olsa Oyun } \backslash \text { Bedensel (Haftada) } \\
\text { Harekette Bulunma Gün Sayısı }\end{array}$} & 1-3 gün & 38 & 67,9 \\
\hline & 4-6 gün & 10 & 17,9 \\
\hline & 7 gün & 8 & 14,3 \\
\hline \multirow{5}{*}{ Oyun ve Egzersiz Sırasında Yaşanan Sorunlar } & Hipoglisemi & 29 & 48,3 \\
\hline & Hiperglisemi & 3 & 5,0 \\
\hline & Keton & 0 & 0 \\
\hline & Hepsi & 1 & 1,7 \\
\hline & Hiçbiri & 27 & 45,0 \\
\hline \multirow{2}{*}{$\begin{array}{l}\text { Beden Eğitimi Öğretmeninin Diyabetli Olduğunu } \\
\text { Bilme Durumu }\end{array}$} & Evet & 50 & 82,0 \\
\hline & Hayır & 11 & 18,0 \\
\hline \multirow{2}{*}{ Beden Eğitimi Derslerine Katılma Durumu } & Evet & 58 & 95,0 \\
\hline & Hayır & 3 & 4,9 \\
\hline \multirow{5}{*}{ Beden Eğitimi Derslerine Katılmama Nedeni } & Hipoglisemi korkusu & 1 & 33,3 \\
\hline & Hiperglisemi korkusu & 0 & 0 \\
\hline & Beden dersini sevmemek & 0 & 0 \\
\hline & Ailesinin istememesi & 1 & 33,3 \\
\hline & Öğretmenin istememesi & 1 & 33,3 \\
\hline
\end{tabular}

Tablo 3. Bilgi Testine Cevap Veren Katılımcıların Doğru Yaptıkları, Yanlış Yaptıkları ve Boş Bıraktıkları Soru Sayılarına Ait Tanımlayıcı İstatistikler

\begin{tabular}{|c|c|c|c|c|c|c|c|c|c|}
\hline & & \multirow{2}{*}{$\mathbf{n}$} & \multirow{2}{*}{ Ortalama } & \multirow{2}{*}{ SS } & \multirow{2}{*}{ Min. } & \multirow{2}{*}{ Maks. } & \multirow{2}{*}{ Medyan } & Kartil & \multirow{2}{*}{$\mathbf{p}$} \\
\hline & & & & & & & & Q1-Q3 & \\
\hline \multirow{2}{*}{$\begin{array}{l}\text { Doğru } \\
\text { Sayısı }\end{array}$} & $\begin{array}{l}\text { Ĕgitim } \\
\text { Öncesi }\end{array}$ & 52 & 16,44 & 5,085 & 5 & 26 & 16,00 & $12,5-18$ & \multirow{2}{*}{0,165} \\
\hline & $\begin{array}{l}\text { Eğitim } \\
\text { Sonrası }\end{array}$ & 52 & 14,77 & 7,532 & 0 & 28 & 12,00 & $5,5-20,5$ & \\
\hline \multirow{2}{*}{$\begin{array}{l}\text { Yanlış } \\
\text { Sayısı }\end{array}$} & $\begin{array}{l}\text { Ĕgitim } \\
\text { Öncesi }\end{array}$ & 52 & 13,37 & 5,329 & 3 & 28 & 14,00 & $9,5-17,5$ & \multirow{2}{*}{0,038} \\
\hline & $\begin{array}{l}\text { Eğitim } \\
\text { Sonrası } \\
\end{array}$ & 52 & 11,15 & 6,870 & 0 & 27 & 9,00 & $3,5-13$ & \\
\hline \multirow{2}{*}{$\begin{array}{l}\text { Boş } \\
\text { Sayısı }\end{array}$} & $\begin{array}{l}\text { Eğitim } \\
\text { Öncesi }\end{array}$ & 52 & 3,04 & 4,121 & 0 & 20 & 1,00 & $0-5$ & \multirow[b]{2}{*}{0,040} \\
\hline & $\begin{array}{l}\text { Eğitim } \\
\text { Sonrası }\end{array}$ & 52 & 6,48 & 8,904 & 0 & 30 & 1,00 & $0-7$ & \\
\hline
\end{tabular}

"Wilcoxon sign rank test, SS: standart sapma, Min: Minimum, Maks: Maksimum, Q1: 1. Kartil, Q3: 3. Kartil. 
Tablo 4. Katılımcıların Eğitim Öncesi ve Sonrası Egzersiz ve Diyabet Hakkındaki Düşünceleri

\begin{tabular}{|c|c|c|c|c|c|c|}
\hline \multirow{2}{*}{\multicolumn{2}{|c|}{ Egzersizde Engeller }} & \multicolumn{2}{|c|}{ Ĕgitim Öncesi } & \multicolumn{2}{|c|}{ Ĕgitim Sonrası } & \multirow[b]{2}{*}{$\mathbf{p}$} \\
\hline & & $\mathrm{n}$ & $\%$ & $\mathrm{n}$ & $\%$ & \\
\hline \multirow{3}{*}{ Diyabet olma } & Evet & 2 & 3,3 & 4 & 8,0 & \multirow{3}{*}{0,465} \\
\hline & Kararsızım & 7 & 11,7 & 5 & 10,0 & \\
\hline & Hayır & 51 & 85,0 & 41 & 82,0 & \\
\hline \multirow{3}{*}{ Hipoglisemi Riski } & Evet & 16 & 26,2 & 13 & 26,5 & \multirow{3}{*}{0,591} \\
\hline & Kararsızım & 12 & 19,7 & 13 & 26,5 & \\
\hline & Hayır & 33 & 54,1 & 23 & 46,9 & \\
\hline \multirow{3}{*}{ Hiperglisemi Riski } & Evet & 5 & 8,3 & 3 & 6,1 & \multirow{3}{*}{0,275} \\
\hline & Kararsızım & 12 & 20,0 & 16 & 32,7 & \\
\hline & Hayır & 43 & 71,7 & 30 & 61,2 & \\
\hline \multirow{3}{*}{$\begin{array}{lll}\text { Egzersiz } & \text { Türüne } & \text { Karar } \\
\text { Verememe } & & \end{array}$} & Evet & 8 & 13,6 & 9 & 18,4 & \multirow{3}{*}{0,381} \\
\hline & Kararsızım & 12 & 20,3 & 7 & 14,3 & \\
\hline & Hayır & 39 & 66,1 & 33 & 67,3 & \\
\hline \multirow{3}{*}{$\begin{array}{l}\text { Egzersizde } \\
\text { Bilememek }\end{array}$} & Evet & 10 & 16,4 & 9 & 18,4 & \multirow{3}{*}{0,477} \\
\hline & Kararsızım & 13 & 21,3 & 12 & 24,5 & \\
\hline & Hayır & 38 & 62,3 & 28 & 57,1 & \\
\hline \multirow{3}{*}{$\begin{array}{l}\text { Egzersiz Süresine Karar } \\
\text { Verememek }\end{array}$} & Evet & 2 & 3,3 & 8 & 16,0 & \multirow{3}{*}{0,170} \\
\hline & Kararsızım & 14 & 23,3 & 7 & 14,0 & \\
\hline & Hayır & 44 & 73,3 & 35 & 70,0 & \\
\hline \multirow{3}{*}{$\begin{array}{l}\text { İnsülin Dozuna Karar } \\
\text { Verememek }\end{array}$} & Evet & 7 & 11,5 & 8 & 16,3 & \multirow{3}{*}{0,727} \\
\hline & Kararsızım & 16 & 26,2 & 8 & 16,3 & \\
\hline & Hayır & 38 & 62,3 & 33 & 67,3 & \\
\hline \multirow{5}{*}{ Fiziksel Aktivite Durumu } & Kötü & 2 & 3,3 & 5 & 10,4 & \multirow{5}{*}{0,060} \\
\hline & $\begin{array}{l}\text { Biraz daha gayret } \\
\text { etmem gerek }\end{array}$ & 11 & 18,0 & 10 & 20,8 & \\
\hline & Orta & 15 & 24,6 & 10 & 20,8 & \\
\hline & İyi & 20 & 32,8 & 16 & 33,3 & \\
\hline & Çok iyi & 13 & 21,3 & 7 & 14,6 & \\
\hline
\end{tabular}

*Wilcoxon Sign Rank Test

Tablo 5.Web Sitesini Değerlendirme Formun 3 Alt Boyutuna Ait Puanların ve Genel Ortalama Puanlarının Tanımlayıcı İstatistikleri

\begin{tabular}{|l|c|c|c|c|c|}
\hline & $\mathbf{n}$ & Ortalama & $\begin{array}{c}\text { Standart } \\
\text { sapma }\end{array}$ & Min. Maks. \\
\hline $\begin{array}{l}\text { Görsel Yeterlilik } \\
\text { Değerlendirme }\end{array}$ & 56 & 3,96 & 0,54 & 2,67 & 5,00 \\
\hline $\begin{array}{l}\text { Teknik Yeterlilik } \\
\text { Değerlendirme }\end{array}$ & 56 & 3,85 & 0,56 & 2,63 & 5,00 \\
\hline $\begin{array}{l}\text { İcerik Değerlendirme } \\
\text { Web Sitesi }\end{array}$ & 55 & 4,04 & 0,59 & 2,46 & 5,00 \\
\hline $\begin{array}{l}\text { Değerlendirme Genel } \\
\text { Ortalama Puanı }\end{array}$ & 56 & 3,96 & 0,51 & 2,96 & 5,00 \\
\hline
\end{tabular}

Min: Minimum, Maks: Maksimum

\section{TARTIŞMA VE SONUÇ}

Bilgisayar ortamında hazırlanan ve internet yoluyla sunulan "diyabette egzersiz eğitimi" modülünün Tip 1 diyabet hastalarına uygulanabilirliğini test etmek ve hastaların, bilgi düzeyi, diyabet yönetimi ve egzersize bakışları üzerine etkilerini belirlemek amacıyla yarı deneysel, prospektif yapılan bu çalışma 61 adölesan ile yürütülmüştür.

Düzenli egzersizin tip 1 diyabetli adölesanlarda kilo kontrolünün sağlanmasında önemli bir yöntem olduğu ve egzersizi hayat tarzı olarak benimsenmesinin metabolik kontrolün sağlanmasında etkili olduğu belirtilmektedir (17). Tip 1 diyabetli adölesanlar kilolu alma eğilimindedir. VKİ arttıkça insülin ihtiyacının arttığını belirtilmektedir (35). Sideraviciūte ve ark. (31) çalıșmasında yaş ortalaması 8 olan 14 tip 1 diyabet hastasına $45 \mathrm{dk}$ egzersiz eğitimi vermişler, ardından hastaların 14 hafta boyunca haftada $2 \mathrm{kez}$ yüzmelerini sağlanmışlardır. Çalışmanın sonunda VKI değişmediği ancak vücut yağ kütlesinin anlamlı olarak azaldığ bulunmuştur ( $\mathrm{p}<0,001)$. Bu çalışmaya katılan bireylerin VKİ ortalamaları ise 20,91 $(\mathrm{SS}=4,43)$ olarak saptand 1 (Tablo 1).

Tip 1 diyabette, başarılı diyabet yönetimi düzenli egzersize dayanmaktadır (41). Altı ile on sekiz yaş arası tüm diyabet hastalarına için her gün 60 dakika veya daha fazla fiziksel aktivite, orta dereceli egzersiz önerilmektedir. ISPAD 2018 konsensus karalarında yüksek yoğunluklu egzersiz ise haftada $3 \mathrm{kez}$ önerilmektedir (13). Tip 1 diyabetli erişkinlerde, haftada en az iki kez düzenli egzersizin 8 hafta sonunda glisemik kontrolde etkili olduğu belirtilmektedir (13). Herbst ve ark. (33) 19,143 tip 1 diyabetli hasta üzerinde yaptıkları çalışmada \%44,8'inin $\quad(n=8589)$ düzenli spor yapmadığını, \%36,8'inin $(\mathrm{n}=7056)$ haftada bir veya iki kez, \%18,2'sinin $(n=3498)$ ise haftada 3 veya daha fazla düzenli spor yaptığı belirlemiştir. Nordfeldt ve ark. (23) ise yaptıkları çalışmada hastaların ve ebeveynlerinin egzersiz sirasında hafif veya şiddetli derecede hipoglisemi yaşama riskini önemli bir problem olarak gördüklerini bildirmiştir. Yapılan bu çalışmada da egzersiz yapma oranlarının düşük olmasının $(\% 53,4)$ egzersiz de yaşanacak akut komplikasyon korkusundan kaynaklandığı düşünülmektedir. Bununla beraber web tabanlı egzersiz eğitimi ile kan şekeri yönetiminin 
sağlanması hem korkuların azalmasına hem de diyabetli adölesanların egzersiz yapmaya cesaretlenmesine yol açacaktır. Yapılan çalışmalar bu korkular nedeniyle tip 1 diyabetli adölesanların yaşıtlarına oranla daha az formda olduğunu göstermektedir (34-36). Yapılan bu çalışmada da egzersiz yapmama oranlarının yüksek olmasının $(\% 46,6)$ egzersiz de yaşanacak akut komplikasyon korkusundan kaynaklandığı düşünülmektedir (Tablo 2). Bununla beraber web tabanlı egzersiz eğitimi ile kan şekeri yönetiminin sağlanması hem korkuların azalmasına hem de diyabetli adölesanların egzersiz yapmaya cesaretlenmesine yol açacaktır (36). Yapılan çalışmalar bu korkular nedeniyle tip 1 diyabetli gençlerin yaşıtlarına oranla daha az formda olduğunu göstermektedir (34-36).

Antje Herbst ve ark. (33) tip 1 diyabetli hastalarda düzenli egzersizin glisemik kontrol üzerine etkisini incelediğinde, egzersiz sıklığının hipoglisemi veya bilinç kaybına kadar gidebilen ağır hipoglisemi için bağımsız bir risk olmadığını belirtmişlerdir. Kendi çalışmalarında şiddetli hipogliseminin ortalama sıklığının yılda \%22,9 olduğunu bildirmişlerdir. Bu çalışmada katılımcıların oyun ve egzersiz sırasında egzersize bağlı; hipoglisemi (\%48,3), hiperglisemi (\%5) gibi sorunlar yaşadıkları belirlendi (Tablo 2). Web tabanlı egzersiz eğitimlerinin tip 1 diyabetlilerin egzersize bağlı hipoglisemiyi önlemelerine yardımcı olacağı, buna yönelik yönetim stratejileri geliştirmede etkili olabileceği tahmin edilmektedir.

Okulda diyabet yönetiminde yaşanılan zorlukların araştırıldığı bir çalışma ilebu çalışmanın sonuçları benzer göstermiştir. Söz konusu çalışmaya katılan bireylerin \%98'i beden eğitimine, \%35,5'i de sportif etkinliğe katıldığını saptamıştır. Bunların \% 7,5'i diyabet hastası olduklarından öğretmenleri ve arkadaşlarının haberdar olmadıklarını beyan etmiştir (37). Bu çalışmada ise \%96,7'si beden eğitimi dersine katıldığı, \%18'nin diyabet hastası olduklarından öğretmenleri ve arkadaşları tarafından bilinmediğini ifade etmiştir (Tablo 2). Benden eğitimi öğretmenleri veya spor eğitmenleri için bu bilgi olası bir ilk yardım müdahalesi için oldukça önemlidir. $\mathrm{Bu}$ durumun okulda geçirilen zaman süresince diyabet yönetimi açısından engel teşkil edebileceği düşünülmektedir. Beden eğitimi derslerine katılmayan bireylerin bunun nedenleri sorulduğunda \%37,5'i hipoglisemi yaşamaktan korktuğu için, \%37,5'i beden dersini sevmediği için, \%25'i de ailesi istemediği için katılmadığını ifade etmiştir. Bireyin kendisi, ebeveynleri ve öğretmeleri tarafindan yaratılan şiddetli hipoglisemi yaşama korkusu diyabetlilerin herhangi bir fiziksel aktiviteye katılmalarını sınırlayan önemli bir faktördür $(38,39)$. Oysa bu konuda destek olan ailelere sahip tip 1 diyabetli adölesanların daha iyi metabolik kontrol ve kişisel bakım davranışlarına sahip olduğu görülmüştür. Tip 1 diyabetli gençlerde fiziksel aktivitedeki ebeveyn rollerine ilişkin bulgular, fiziksel aktivite yapma isteğinin ebeveynler ve erken-orta adölesan dönemindeki çocuklar arasında bir çatışma alanına dönüştüğünü göstermektedir (40).

Çövener (41), tip 1 diyabet yönetiminde sağlığı geliştirme modeli ve tam öğrenme kuramına dayalı eğitimin etkisini incelediği çalışmasında dokuz ünitelik yüz yüze eğitim uygulamıştır. Ünite bitimlerinde ve verilen eğitim programı öncesi, sonrası ve programın bitiminden üç ay sonra 25 sorudan oluşan sınav uygulamıştır. Eğitim öncesinde puan ortalaması 37 $\pm 12,94$ (min:12-maks:56), eğitim sonrasında 8 . Gün $62 \pm 15,24$ (min:32-maks:88) ve eğitimden 3 ay sonra 56,11 $\pm 15,07$ (min:28-maks:84) bulunmuştur. Puan ortalamaları karşılaştırıldığında eğitim öncesi puan ortalaması ve eğitim sonrası (8.gün) puan ortalamaları istatistiksel olarak ileri düzeyde anlamlı farklılık göstermektedir ( $\mathrm{p}<0,001)$. Okuroğlu (42) yaptığı Web Tabanlı Tip 2 Diyabet Eğitim Programı ile 44 hemşireye diyabet eğitimi verilmiştir. Tüm eğitimi tamamlayan 41 katılımcının ünite değerlendirme testi ön test puan ortalamasinın $40,50 \pm 8,29$, son test puan ortalamasının ise $73,30 \pm 8,67$ olduğu ve ön test son test puan ortalamaları arasında istatistiksel olarak anlamlı fark olduğu tespit edilmiştir $(Z=-5,513, p<0,001)$. Wilkinson ve ark. (43) dört modülden oluşan web tabanlı eğitimin etkinliğini değerlendirmek amacıyla yaptıkları çalışmada, hemşirelerin diyabet modülüne ilişkin ön test-son test puanları arasında anlamlı düzeyde fark olduğu saptanmıştır. Bu çalışmada ise doğru cevap sayıları kıyaslandığında eğitim öncesi ve sonrası arasında anlamlı bir fark görülmez iken, yanlış cevap sayısı eğitim sonrasında anlamlı bir azalış gösterdiği belirlendi (Tablo 3). Ayrıca literatür incelendiğinde web tabanlı diyabet eğitim etkinliklerinin çoğunlukla diyabetli adölesanlar için geliştirildiği ve bu çalışmalarda web tabanlı eğitiminin diyabetli adölesanların hastalığa ilişkin bilgilerini arttırdığ ve metabolik kontrollerini iyileştirdiği söylenmektedir (20,44-47). Bu durum tip 1 diyabetli adölesanlara yönelik web tabanlı egzersiz eğitimleri ile bilgi düzeylerinin artacağını ve buna bağlı olarak egzersiz yapmaya cesaretlenmelerinde etkili olacağını düşündürmektedir

Egzersizde hipoglisemi veya hipergliseminin genellikle egzersiz sırasında veya hemen sonrasında ortaya çıktığ bildirilmektedir (13). Nordfeldt ve ark. (14) Tip 1 diyabetli çocuk ve adölesanların hastalıkla ilgili korkularını inceledikleri çalışmalarında 112 diyabetli adölesanlar ve ebeveynlerinin özellikle egzersizde hafif ve şiddetli hipoglisemi yaşama riskini problem olarak gördüklerini bildirmiştir. Brazeau ve ark. (15) "Tip 1 Diyabetli Hastalarda Fiziksel Aktivitenin Engelleri” isimli çalışmasında 100 katılımcıya engel olarak algıladığı konuları değerlendiren BAPAD1 (the Barriers to Physical Activity in Diabetes type 1 scale) isimli ölçek uygulamıştır. Fiziksel aktivite yapmaya en büyük engelin hipoglisemi korkusu (en yüksek ortalama puan $3,58 \pm 2,02$ ) olduğunu saptamıştır. Yapılan bu çalışma ile literatürdeki bulgular benzerlik göstermektedir. Bu çalışmada katılımcılar tarafından, egzersiz türüne karar verememek, egzersizde beslenmeyi bilememek, egzersiz süresine ve insülin dozuna karar verememekte egzersize engel durumlar olduğu belirlendi (Tablo 4). Bu durum tip 1 diyabetli adölesanlara ve ailelerine egzersizde kan şeker yönetimi konusunda daha fazla eğitim verilmesi gerektirdiğini düşündürmektedir.

Lukacs ve ark. (34) 106 tip 1 diyabetli ve 130 sağlıklı genç ile yaptığı çalışmada diyabetli gençlerin üst ekstremite hareketi, karın kas kuvveti, üst vücut kuvveti ve koşu hızlarının daha düşük olduğu saptamıştır. Williams ve ark. (35) 5-14 yaşları arasında 88 Tip 1 diyabetli çocuğa adım testi uygulamış ve kardiyorespiratuar zindelik seviyelerinin kontrol 
grubundan düşük olduğunu saptamıştır. $\mathrm{Bu}$ durumun daha düşük fiziksel aktivite seviyelerine sahip olduklarından kaynaklandığını düşündürmektedir. Yapılan bu çalışma katılımcıların eğitim sonrası \%57,1'nin egzersiz yapmakta kararlı olduğu belirlendi. $\mathrm{Bu}$ bağlamda komplikasyonu olmayan ve iyi glisemik kontrolü olan tip 1 diyabetli hastalar tarafindan hem spor amaçlı hem de profesyonel amaçlı fiziksel aktivitelerin yapılabileceği bildirilmektedir (48).

Okuroğlu'nun yaptığı Web Tabanlı Tip 2 Diyabet Eğitim Programında (WTEP) Web Tabanlı Eğitim Materyali Değerlendirme Ölçeğieene verdikleri yanitlar doğrultusunda madde puan ortalamalarının 4,52 $\pm 0,41(\min =3,96-$ maks $=5,00)$ olduğu saptanmıştır. Bu bulgu çalışma grubunun WTEP'i 'çok iyi' olarak değerlendirdiği şeklinde yorumlanmıştır (42). Whittemore et al. (49) yaş ortalaması 14,4 olan tip 1 diyabetli 12 bireye 6 ay web tabanlı TEENCOPE isimli 5 oturumdan oluşan eğitim verilmiştir. Çalışma sonunda beş maddelik bir memnuniyet anketi ve programları iyileştirme yolları hakkında açık uçlu bir soru sorulmuştur. Katılımcıların \% 90'ı bunu beğendiğini, \% 90'1 açık ve ilginç olduğunu ve \% 80'i sitenin gençler için uygun olduğunu bildirmiştir. Literatür sonuçlarına göre web tabanlı diyabet eğitimleri tip 1 diyabetli çocuk ve adölesanların dikkatlerini çekmekte ve ilgi göstermektedir. Web tabanlı hazırlanan programların içeriğine yönelik akran etkileşiminin sağlanmasının doğru bilgi kaynağına ulaşılmasının ve sağlık profesyonelleri ile iletişime geçme imkanı olmasının web tabanlı eğitimleri ilgi çekici kıldığı düşünülmektedir. Bu çalışmada da Web Sitesi Değerlendirme Formundan alınan puanlar (genel toplam ve alt boyutlardan alınan puanlar) çalışma için hazırlanan web sitesinin iyi olduğunu göstermektedir (Tablo 5). Bu veriler 1şı̆̆ında web tabanlı egzersiz eğitimi ile egzersiz tip 1 diyabetli çocuk ve adölesanların yaşamlarına uyarlamalarında etkili olabileceği düşünülmektedir (24).

$\mathrm{Bu}$ çalışmada araştırmaya katılan tip 1 diyabetli adölesanların eğitim öncesi ve sonrası diyabette egzersiz ile ilgili bilgi düzeyinde anlamlı bir artış olduğu (yanlış sayısında eğitim sonrası anlamlı bir azalma meydana geldiği) ve eğitim sonunda katılımcıların fiziksel aktivite durumları için kararlı bir şekilde egzersiz yapmak istediği ve olumlu dönüşümler yaptığı saptanmıştır. Daha önce yapılan çalışmalarda da bildirildiği gibi web tabanlı diyabet eğitiminin katılımcılar üzerinde olumlu yönde etkisi olduğu söylenebilir. Ayrıca çalışmada düzenlenen web tabanlı egzersiz eğitim sitesinin kullanılabilirliği değerlendirildiğinde ortalama puanın yüksek olması bu sistemin uygulanabilir ve kabul edilebilir olduğunu belirlenmiştir.

Gelecekte yapılması planlanan araştırmalarda, ülkemizde ve dünyada yükselen internet kullanım oranlarının artması nedeni ile diyabetli çocuk ve adölesanlara ulaşmak ve bir araya getirerek, sosyal destek sağlama konusunda sinırlı sayıda olan web tabanlı pediatrik diyabet eğitim programlarının sayısı arttırılabilir. Web tabanlı egzersiz eğitimi ile egzersize bağlı hiperglisemiyi ve hipoglisemiyi önlemek için diyabetli adölesanların kişisel bir strateji (yani, karbonhidrat alımı veya insülin dozajının azaltılması) oluşturulmasına katkı sağlayabilir.

\section{TEŞEKKÜR}

Araştırmaya katılan tüm diyabetli adölesanlara katkılarından dolayı teşekkür ederiz. Bu araştırma Düzce Üniversitesi BAP- 2017.16.01.619 numaralı Bilimsel Araştırma Projesiyle desteklenmiştir. $\mathrm{Bu}$ makalenin yazımında araştırma ve yayın etiği kurallarına uyulmuştur. Yazarlar arasında herhangi bir çıkar ilişkisi olmadığını beyan ederiz.

Yazarların Katkıları: Fikir/Kavram: S.A., İ.A; Tasarım: S.G., S.A., İ.A; Veri Toplama ve/veya İşleme: S.G.; Analiz ve/veya Yorum: S.G., S.A.; Literatür Taraması: S.G.; Makale Yazımı: S.G.; Eleştirel İnceleme: İ.A.

\section{KAYNAKLAR}

1. American diabetes association. Classification and diagnosis of diabetes: standards of medical care in diabetes. Diabetes Care. 2018; 41(1): 13-27.

2. American diabetes association. Children and adolescents: standards of medical care in diabetes. Diabetes Care. 2019; 42(1): 148-64.

3. Diabetes atlas 2017 [Internet]. Belgium; International Diabetes Federation; [Cited: 2019 Sep 19]. Available from: $\quad$ http://fmdiabetes.org/wpcontent/uploads/2018/03/IDF-2017.pdf.

4. Smart CE, Annan F, Higgins LA, Jelleryd E, Lopez $\mathrm{M}$, Acerini CL. Internation society for pediatric and adolescent diabetes clinical practice consensus guidelines 2018: nutritional management in children and adolescents with diabetes. Pediatr Diabetes. 2018; 19(27): 136-54.

5. Parent KB, Wodrich DL, Hasan KS. Type 1 diabetes mellitus and school: a comparison of patients and healthy siblings. Pediatric Diabetes. 2009; 10(8): 55462.

6. Jefferies C, Rhodes E, Rachmie M, Chizo AJ, Kapellen T, Abdulla MA, et al. Internation society for pediatric and adolescent diabetes clinical practice consensus guidelines 2018: management of children and adolescents with diabetes requiring surgery. Pediatric Diabetes. 2018; 19(27): 227-36.

7. Felton AM, Hall M. Diabetes in Europe policy puzzle: the state we are in. International Diabetes Nursing. 2015; 12(1): 3-7.

8. Ayar D, Öztürk C. Tip 1 diyabetik ergenlerin eğitiminde yeni yaklaşımlar web tabanlı eğitim. Dokuz Eylül Üniversitesi Hemşirelik Fakültesi Elektronik Dergisi. 2015; 8(3): 184-9.

9. Canadian diabetes association clinical practice guidelines expert committee, Cheng AY. Canadian diabetes association 2013 clinical practice guidelines for the prevention and management of diabetes in Canada. Introduction. Canadian Journal of Diabetes. 2013; 37(1): 1-3.

10. Karaca SS, Ergüney S. The effect of planned education given to the patients with type-2 diabetes mellitus on the attitudes, well-being and metabolic control variables of the patients. Diyabet, Obezite ve Hipertansiyonda Hemşlirelik Forumu Dergisi. 2009; 1(2): 40-9.

11. Phelan H, Lange K, Cengiz E, Gallego P, Majaliwa E, Pelicand $\mathrm{J}$, et al. Internation society for pediatric and adolescent diabetes clinical practice consensus 
guidelines 2018: diabetes education in children and adolescents. Pediatric Diabetes. 2018; 19(27): 75-83.

12. Martin D, Lange K, Sima A, Kownatka D, Skovlund $\mathrm{S}$, Danne $\mathrm{T}$, et al. Recommendations for ageappropriate education of children and adolescents with diabetes and their parents in the European union. Pediatr Diabetes. 2012; 13(16): 20-8.

13. Adolfsson P, Riddell MC, Taplin CE, Davis EA, Fournier PA, Annan F, et al. Internation society for pediatric and adolescent diabetes clinical practice consensus guidelines 2018: exercise in children and adolescents with diabetes. Pediatric Diabetes.2018; 19(27): 205-26.

14. Nordfeldt S, Ludvigsson J. Fear and other disturbances of severe hypoglycaemia in children and adolescents with type 1 diabetes mellitus. Journal of Pediatric Endocrinology and Metabolism. 2005; 18(1): 83-91.

15. Brazeau AS, Rabasa-Lhoret R, Strychar I, Mircescu H. Barriers to physical activity among patients with type 1 diabetes. Diabetes Care. 2008; 31(11): 2108-9.

16. Oram RA, Patel K, Hill A, Shields B, McDonald TJ, Jones A, et al. A type 1 diabetes genetic risk score can aid discrimination between type 1 and type 2 diabetes in young adults. Diabetes Care. 2016; 39(3): 337-44.

17. Lange K, Klotmann S, Saßmann H, Aschemeier B, Wintergerst E, Gerhardsson $\mathrm{P}$, et al. A pediatric diabetes toolbox for creating centres of reference. Pediatr Diabetes. 2012; 13(16): 49-61.

18. Wearesocial.com [Internet]. Digital in 2018: world's internet users pass the 4 billion mark [Updated: 2018 Jan 30; Cited: 2019 Feb 15]. Avaible from: https://wearesocial.com/us/blog/2018/01/globaldigital-report-2018.

19. Tuik.gov.tr [İnternet]. 06-15 Yaş grubu çocuklarda bilişim teknolojileri kullanımı ve medya [Son güncelleme tarihi: 22 Ağustos 2013; Erişim tarihi: 15 Mayıs 2019]. Erişim adresi: http://www.tuik.gov.tr/VeriBilgi.do?id= .

20. Avdal EÜ, Kızılcı S, Demirel N. Web tabanlı verilen diyabet eğitiminin bakım sonuçlarına etkisi randomize kontrollü çalışma. Diyabet, Obezite ve Hipertansiyonda Hemşirelik Forumu Dergisi.2011; 3(1): 39-48.

21. Newton KT, Ashley A. Pilot study of a web-based intervention for adolescents with type 1 diabetes. Journal of Telemedicine and Telecare. 2013; 19(8): 443-9.

22. Pinsker JE, Nguyen C, Young S, Fredericks GJ, Chan D. A pilot project for improving paediatric diabetes outcomes using a website: the pediatric diabetes education portal. Journal of Telemedicine and Telecare. 2011; 17(5): 226-30.

23. Hanberger L, Ludvigsson J, Nordfeldt S. Use of a web 2.0 portal to improve education and communication in young patients with families: randomized controlled trial. Journal of Medical Internet Research. 2013; 15(8): 175.

24. Whittemore R, Grey M, Lindemann E, Ambrosino J, Jaser S. Development of an internet coping skills training program for teenagers with type 1 diabetes. Computers, Informatics, Nursing. 2010; 28(2): 10311.
25. Whittemore R, Jaser SS, Jeon S, Liberti L, Delamater, A, et al. An internet coping skills training program for youth with type 1 diabetes. Nursing Research. 2012; 61(6): 390-403.

26. Gusso S, Pinto TE, Baldi JC, Robinson E, Cutfield WS, Hofman PL. Diastolic function is reduced in adolescents with type 1 diabetes in response to exercise. Diabetes Care. 2012; 35(10): 2089-94.

27. Çetin O. Fen ve teknoloji dersinde "Çoklu ortam tasarım modeline", göre hazırlanmış web tabanlı öğretim içeriğinin öğrenci başarı ve tutumlarına etkisi ile içeriğe yönelik öğretmen ve öğrenci görüşlerinin değerlendirilmesi [Doktora Tezi]. İzmir: Dokuz Eylül Üniversitesi Eğitim Bilimleri Enstitüsü; 2010.

28. American diabetes association. Classification and diagnosis of diabetes: standards of medical care in diabetes. Diabetes Care. 2018; 41(1): 13-27.

29. Temd.org [İnternet]. Diabetes mellitus ve komplikasyonlarinin tanı, tedavi ve izlem k1lavuzu 2019 [Son güncelleme tarihi: Ağustos 2019; Erişim tarihi: 31 Ağustos 2019]. Erişim adresi: http://www.temd.org.tr/admin/uploads/tbl gruplar/20 190819095924-2019tbl_gruplar9e6fbbc8c2.pdf

30. Kocabaş A, Kocabaş BA, Karagüzel G, Akçurin S. Tip 1 diyabetes mellitus olgularımızın antropometrik ve metabolik izlem özelliklerinin değerlendirilmesi. Türkiye Çocuk Hastalıkları Dergisi. 2013;7(3): 113-8.

31. Sideraviciūte S, Gailiūniene A, Visagurskiene K, Vizbaraite D. The effect of long-term swimming program on body composition, aerobic capacity and blood lipids in 14-19-year aged healthy girls and girls with type 1 diabetes mellitus. Medicina (Kaunas). 2006; 42(8): 661-6.

32. Silverstein J, Klingensmith G, Copeland K, Plotnıck L, Kaufman F, Laffel L, et al. Care of children and adolescents with type 1 diabetes. Diabetes Care. 2005; 28(1): 186-212.

33. Herbst A, Bachran R, Kapellen T, Holl RW. Effects of regular physical activity on control of glycemia in pediatric patients with type 1 diabetes mellitus. Archives of Pediatrics and Adolescent Medicine. 2006; 160(6): 573-7.

34. Lukacs A, Mayer K, Juhasz E, Varga B, Fodor B, Barkai L. Reduced physical fitness in children and adolescents with type 1 diabetes. Pediatr Diabetes. 2012; 13(5): 432-7.

35. Williams BK, Guelfi KJ, Jones TW, Davis EA. Lower cardiorespiratory fitness in children with type 1 diabetes. Diabetic Medicine. 2011; 28(8): 1005-7.

36. Tsalikian E, Mauras N, Beck RW, Tamborlane WV, Janz KF, Chase HP, et al. Impact of exercise on overnight glycemic control in children with type 1 mellitus. The Journal of Pediatrics. 2005; 147(4): 52834.

37. Tarı S, Kitiş Y. Tip 1 diyabetli çocukların okulda diyabet yönetimiyle ilgili yaşadıkları güçlükler. Ege Üniversitesi Hemşirelik Fakültesi Dergisi. 2016; 32(2): 44-60.

38. Johnson SR, Cooper MN, Davis EA, Jones TW. Hypoglycaemia, fear of hypoglycaemia and quality of life in children with type 1 diabetes and their parents. Diabetic Medicine. 2013; 30(9): 1126-31. 
39. Pate T, Klemencic S, Battelino T, Bratina N. Fear of hypoglycemia, anxiety, and subjective well-being in parents of children and adolescents with type 1 diabetes. Journal of Health Psychology. 2019; 24(2): 209-18.

40. American Diabetes Association. Lifestyle management: standards of medical care in diabetes. Diabetes Care. 2018; 41(1): 38-50.

41. Çövener Ç. Tip 1 diyabet yönetiminde sağlı̆̆ geliştirme modeli ve tam öğrenme kuramına dayalı eğitimin etkisi [Doktora Tezi]. İstanbul: Marmara Üniversitesi Sağlık Bilimleri Enstitüsü; 2012.

42. Okuroğlu GK. Sağlık çalışanlarına yönelik web tabanlı tip 2 diyabet eğitim programının geliştirilmesi ve etkinliğinin değerlendirilmesi [Doktora Tezi]. İstanbul: Marmara Üniversitesi Sağlık Bilimleri Enstitüsü; 2015.

43. Wilkinson A, Forbes A, Bloomfield J, Fincham Gee C. An exploration of four web-based open and flexible learning modules in post-registration nurse education. International Journal of Nursing Studies. 2004; 41(4): 411-24.

44. McMahon GT, Gomes HE, Hohne SH, Hu TM, Levine BA, Conlin PR. Web-based care management in patients withs poorly controlled diabetes. Diabates Care. 2005; 28(7): 1624-9.

45. Gerber BS, Brodsky IG, Lawless KA, Smolin LI, Arozullah AM, Smith EV, et al. Implementation and evaluation of a low-literacy diabetes education computer multimedia application. Diabetes Care. 2005; 28(7): 1574-80.

46. Porter SJ, Chapman-Novakofski KM, Scherer JA. Your guide to diet and diabetes: web-based diabetes education tailored to hispanics. Journal of Nutrition Education and Behavior. 2005; 41(5): 374-6.

47. Heinrich E, Nooijer J, Schaper NC, Schoonus-Spit MH, Janssen MA, Vries NK. Evaluation of the webbased diabetes interactive education programme (DIEP) for patients with type 2 diabetes. Patient Education and Counseling. 2012; 86(2): 172-8.

48. Zinman B, Ruderman N, Campaigne BN, Devlin JT, Schneider SH. Physical activity/exercise and diabetes. Diabetes Care. 2004; 27(1); 58-62.

49. Whittemore R, Grey M, Lindemann E, Ambrosino J, Jaser S. Development of an internet coping skills training program for teenagers with type 1 diabetes. Computers, Informatics, Nursing. 2010; 28(2): 10310. 